\title{
Research on the Development of Private Lending in Liaoning
}

\author{
Yue Wang ${ }^{1}$ \\ ${ }^{1}$ Bohai University, Jinzhou, Liaoning Province, China
}

Keywords: Private Lending; Private Capital; Micro-Finance; Measures.

\begin{abstract}
With the development of private economy, private lending in Liaoning province now has reached a considerable scale. This paper aims to analyze the current situation of private lending in Liaoning province, and make comprehensive analysis on specific factors that hinder the healthy development of private lending in Liaoning. On that basis, suggestions which can promote the healthy and stable development of private lending of Liaoning are proposed. Nowadays, the development and expansion of private economy has become an inevitable trend in China's economic development. The author hopes that this paper can provide certain guiding significance, and help private lending in Liaoning province to play a more powerful role in the economic growth.
\end{abstract}

\section{Introduction}

With the rapid development of China's market economy, the private economy has been developing rapidly under the impetus of reform and opening up policy. Private economy now ushers in the opportunity of rapid development. Liaoning province is one of the most important industrial provinces in our country, and it is also an important province in the Northeast China old industrial base. By 2014, the added value of the private economy in Liaoning increased by $7.2 \%$. The private enterprises and private economy have become the main driving force of economic growth in Liaoning province. Private lending in Liaoning province completely adapts to the inevitable contradiction between supply and demand of financing in the financial market. It can make up the shortcomings of formal financial institutions, alleviate the financing difficulties of small and medium enterprises, and greatly promote the rapid development of private economy, as well as the development of small and medium-sized enterprises. However, now in Liaoning province, the good and the bad phenomena are intermingled in the private lending market; the risk of private lending is increasing. As more and more problems are exposed in the face of the public, all sectors of society have to pay attention to solve these problems and promote the formal development of private lending.

\section{Current Situation of Private Lending in Liaoning}

The rapid development of private economy and the increasing scale of private lending. Liaoning province is a famous industrial province in China. For a long time, the proportion of private enterprises in Liaoning has been increasing. Private enterprises grow fastest in the market. By 2014, the total economic output of Liaoning reached 2 trillion 862 billion and 660 million yuan, ranking 7 in the country; GDP per capita reached 65 thousand 201 yuan, increased 5.7\% over the same period last year. Private enterprises have become the main driving force of economic growth in Liaoning province. According to relevant data, the number of private enterprises now accounts for more than $90 \%$ of the total number of enterprises in Liaoning, while the number of financial capital accumulation is also impressive. [1] It can be predicted that for a long period in the future, the development pace of small and medium sized enterprises in Liaoning province will continue to accelerate, and the dominant position of private enterprises in provincial economy will not be shaken. Consequently, their credit demands will continue to grow, which encourage private capital to enter the field of consumer finance, and play an important role in the private lending of Liaoning province.

Main bodies of private lending are various; their active degrees are different. In recent years, the overall development of monetary and financial environment of Liaoning is moderate; private economy develops rapidly; private lending activities are very active. With the reform of financial system, different economic entities begin to turn to private lending agencies. In addition to private 
economy entities like families, individual businesses and farmers, some small and medium-sized state-owned enterprises also choose to financing through private lending agencies. [2] But the active degrees between these economy entities are significant different.

Financing channels of private lending are diversified. With the development of the private lending in Liaoning, the main bodies of the economy are diversified, and the financing channels are becoming more and more diverse. In the survey of small and medium-sized enterprises in Liaoning province in 2015, among sample companies which are involved in private lending activities, $80 \%$ of their loan funds come from shareholders, employees and the society; the rest amount comes from banks, other financial institutions and other channels. Besides these direct financing methods, more and more private financial institutions begin to provide indirect private lending methods such as pawn shops and small loan companies. Some private financial organizations with high reputation choose to obtain loans from official financial institutions with lower interest rates, and then lend the money to small and medium-sized enterprises with higher interest rates to get financial benefits.

The scales of private lending in different regions are significantly different. In the 14 prefecture level cities and two sub provincial cities of Liaoning province, the regional differences of private lending development are significant. In cities and counties with rapid economic development speed and large economy scales, private economy develops rapidly; private capital accumulates quickly. Thus, the development of private lending is active. Generally speaking, in Liaoning province, Shenyang and Dalian take dominant positions in the development of private economy. Therefore, private lending activities are relatively active in these two areas. Moreover, in areas with different levels of economic development, the development forms and characteristics of private lending are also different. In regions with rapid economic development speed like Shenyang and Dalian, private lending has gradually turned to financing; but in other relatively backward regions, private lending still maintains the traditional lending forms like capital raising and free credit.

\section{Existing Problems in Private Lending in Liaoning}

Laws and regulations are not perfect. The current financial legal system on private lending in China is not perfect; relevant laws and regulations are inadequate. Not only in Liaoning province, now the whole country of China still implements provisions and laws on private lending issued at the beginning of 1990s. Relevant laws and regulations include General Principles of the Civil Law, Contract Law and Opinions on Trying Lending Cases from the Supreme People's Court; these provisions obviously lag behind the development situation of private lending. Until 2015, the Supreme People's Court issued the Regulations on Issues of Applicable Laws on Trying Lending Cases, and offered the latest judicial interpretations of private lending. But the lag of laws and regulations makes private lending disputes occur frequently. This problem not only restricts the development of private lending, but also exerts negative impacts on the public.

Management confusion and the lack of effective supervision. At present, the regulation of private lending in Liaoning province is in confusion. In Liaoning province, the regulation of private lending is not implemented by one unit or department. People's government of Liaoning province is responsible for the supervision and establishment of small loan companies; pawn shops are supervised by regulatory system of the Commerce Department; the supervision of small loan companies' fund-raising and application situations attributable to People's Bank of China. Too many regulatory authorities seriously inhibit the development of private lending, and bring unnecessary costs. Multi supervision will lead to unclear responsibilities among regulators, and seriously restrict the sustainable development of private lending in Liaoning province.

High interest rates impact financial markets. The pursuit of profit is the instinct of contemporary economic men. The credit interest rates of private lending agencies are higher than other financial institutions, while their tax burdens are lower than other formal financial institutions. The high profits will inevitably lead some enterprises to separate from industrial entities, and use the leverage of lending to make huge profits. In this process, the level of interest rates is the key to determine their income. At present, there are no clear regulations on private lending rates in China. In 
the absence of financial supervision and management, irrational and illegal private lending behaviors may occur and endangers the financial market.

Lack of self-discipline lead to frequent illegal acts. Currently, private lending is free from government supervision system, and lack of self-discipline. So in recent years in Liaoning, it is often used by criminals. Illegal acts, such as usury, illegal fund-raising and illegal underground banks, occur frequently. Especially recently, with the development of electronic technology and network finance, some illegal P2P network lending behaviors take place in private lending industry. Since private lending is characterized by loose, flexible and convenient, it is easily to go wrong without proper supervision. These illegal cases seriously impact the private lending market, and damage the social trustworthiness of private lending.

High risk of private lending. As capital business institutions, existing private lending institutions in Liaoning are facing with a variety of financial risks. The main parts of their funds come from private capital and shareholders of the company, which cost higher than the bank. Sometimes, the limited capital is difficult to meet the market demands from many borrowers. Fund liquidity risk occurs under that situation. Meanwhile, private lending institutions do not belong to formal financial institutions, and they are unable to obtain support from bank credit database. Borrower information they collected cannot be completely reliable, which lead to high credit risks of private lending industry.

\section{Suggestions to Promote the Healthy Development of Private Lending in Liaoning}

Improving relevant laws and regulations and increasing publicity efforts. In 2015, the Supreme People's Court issued the Regulations on Issues of Applicable Laws on Trying Lending Cases, and offered the latest judicial interpretations of private lending. Combined with the current economic and social development levels of China, it makes specific provisions on private lending from several aspects. Secondly, the government of Liaoning should attach importance to the publicity of legal private lending through various media channels. Judicial departments should increase publicity, too, in order to let the public fully understand laws and regulations on private lending. Strict supervisions should be made to crack down the illegal operation of private lending. At the same time, public investors also need to impart legal knowledge, enhance self-protection and risk prevention awareness, in order to protect their legitimate rights and interests in private lending activities. [3]

Establishing and improving a unified regulatory system. A unified financial supervision system on private lending should be established as soon as possible, in order to fully grasp the information of private lending activities, provide positive guidance and strict supervision, and encourage the regulated management of private lending. The original decentralized regulatory departments should be integrated. Secondly, major regulatory responsibilities should be attributing to one or two financial regulators, in order to improve the supervision efficiency. Furthermore, the China Banking Regulatory Commission need to review the business qualification of non-financial institutions, establish new access rules of private lending market, and monitor the floating of lending rate. Finally, combined with successful experiences from other regions, a reasonable market exit mechanism for private lending institutions should be established to guide the reasonable transformation and development of private lending institutions.

Vigorously promoting the marketization of interest rates to prevent speculation. Interest rates influence the development of capital market. With the standardized development of private lending in Liaoning, before the full implementation of interest rate liberalization, the maximum interest rates of private lending businesses should be limited. [4] During this process, interest rates of banks and other financial institutions may serve as the benchmark. Many factors, including the differences between areas, industries, levels of profitability, as well as the uses and period of credit should be considered to set up reasonable and differentiated interest rates limitation for private lending agencies.

Guiding and encouraging self-discipline and compliance management in private lending. The supervisory departments of the Liaoning provincial government must strengthen the supervision of private lending institutions, but what's more important is to guide and encourage the rational 
operation and self constraint of private lending institutions to realize the benign development of private lending industry. First of all, they need to recognize the legal and social status of private lending companies. [5] Secondly, the Liaoning provincial government should refine the classification of private lending business, and develop specific implement rules and regulations according to the attributes and economic effects of different behaviors. Finally, the urgent affair of the moment is how to drive the standard and compliance development of private lending institutions in Liaoning province. The supervisory departments need to point out the development direction of private lending, offer sufficient space to encourage the development of private lending through interest rates and preferential tax policies, and actively encourage private lending institutions to establish modern enterprise management systems.

Improving the comprehensive risk control mechanism of private lending. To reduce the risk of private lending in Liaoning, it is necessary to improve the risk control and management mechanism as soon as possible. Private lending institutions need to establish their own internal risk control mechanisms, while financial supervision institutions also need to play their roles. First of all, for private lending institutions in Liaoning, it is necessary to strengthen the operational risk and risk management awareness of leaders and business operators. Secondly, external financial regulatory institutions ought to strengthen their supervision and management of private lending industry. Specialized agencies should be established to strengthen the supervision on the daily operations of private lending institutions. An information platform on private lending supervision can also established to effectively prevent credit risks and regulate the development of private lending.

\section{Conclusions}

In a word, private lending is an innovative way of private financing. It plays an important role in the sustainable development of China's economy. In recent years, in Liaoning province and even across the country, private lending is developing in rapid pace. To a certain extent, it promote the rational allocation of financial capital market, and has become a necessary part in financial organization system. However, as a new kind of credit model, the lack of laws, regulations and regulatory mechanism lead to the defects and risks of private lending industry. Based on the analysis of the current situation of private lending in Liaoning, this paper finds out the main factors that hinder the healthy development of private lending in Liaoning province. Then puts forward to countermeasures to solve these problems. The legal status of private lending institutions should be established; supervision and management departments should take responsibility of the development of lending institutions; internal and external management mechanisms are both needed to enhance the level of risk management; the liberalization of interest rates should be accelerated. Private lending institutions should be guided to gradually transform into formal financing institutions. Under governments' preferential policies, private lending industry in Liaoning province can develop healthily and continuously.

\section{References}

[1] Z.K. Zhang, Research on the Current Situation of Private Lending in China. Minzu University of China, 2010

[2] Y. Wei, Study on Private Lending Market in Rural China, Economic Management Press, Beijing, 2013.

[3] D.L. Zhang, Private lending in China: current situation, causes, effects and Countermeasures, J. Financial Accounting. 10 (2004).

[4] G.J. Fang, Standardization of Private Lending, East China University of Political Science and Law, Shanghai, 2014.

[5] P. Luo, Boundary of private lending and illegal fund-raising from the perspective of behavioral pattern, J. Times Finance. 10 (2013). 